\title{
NEW OR LITTLE-KNOWN EPIPHYLLOUS LIVERWORTS, XXIV. A COLLECTION MADE IN THE VENEZUELAN GUAYANA AT THE FOOT OF SALTO ANGEL WITH DESCRIPTION OF COLOLEJEUNEA BENCEI
}

\author{
T. Pócs \\ Department of Botany, Institute of Biology, Eszterházy Károly University \\ H-3301 Eger, Pf. 43, Hungary; E-mail: pocs.tamas33@gmail.com
}

(Received: 7 January 2021; Accepted: 8 March 2021)

\begin{abstract}
A liverwort collection by Bence Pócs from the Venezuelan Guayana resulted in 31 species of liverworts, including Cololejeunea bencei new to science and C. cardiocarpa, C. obliqua, C. platyneura, C. schusteri, C. verwimpii, Lejeunea pulchra and Plagiochila crispabilis new to Venezuela. The distribution and differentiation of C. schusteri is discussed.
\end{abstract}

Key words: Cololejeunea, Guayana Highlands, Neotropics, new species, Venezuela

\section{INTRODUCTION}

During the October of 2001 my son Bence Pócs made a major trip on the tepuis of the Venezuelan Guayana. He made collections of mostly epiphyllous liverworts at my request close to Angel Falls (Salto Angel) in the foothills of Auyán-tepui. As a result, he collected 32 species of liverworts and 2 species of mosses. From the collection a strange looking Cololejeunea species turned to be new to science and further 7 liverwort species were new to Venezuela.

The locality of the specimens, unless indicated otherwise, is: Bolivar state, Municipio Gran Sabana, foothills of Auyán-tepui SW of Canaima, at a ridge E of Rio Churún valley and Angel Falls (Salto Angel), on the way to viewpoint Mirador Laime, between 600 and 1,000 m elevation, in wet submontane rainforest, coll. B. Pócs (01161), 31 October 2001. I added a few records of the enumerated species from other collections; in the latter case their localities are given. All specimens were identified by the author and deposited in the herbarium of Eszterházy Károly University, Eger, Hungary (EGR). 


\section{DESCRIPTION OF THE NEW SPECIES \\ Cololejeunea bencei Pócs, spec. nova}

(Fig. 1)

Subgen. Pedinolejeunea Benedix ex Mizut., J. Hattori Bot. Lab. 24: 240, 1961

Diagnosis: The new species differs from other members of subgen. Pedinolejeunea by the combination of broadly ovate leaves, in most cases with acuminate apex and often interruptedly hyaline border, and by the moderately compressed perianth with a strongly inflated ventral segment and umbilicate apex without beak.

Type: Venezuela, Bolivar state, Municipio Gran Sabana, on the ridge E of Rio Churún valley and of Angel Falls (Salto Angel) SW of Canaima, on the way to viewpoint Mirador Laime, between 600 and 1,000 m elevation, wet submontane rainforest, epiphyllous, rare, coll. B. Pócs $(01161 / H), 31$ October 2001 (holotype: EGR). Etymology: Named after its collector (Bence is an old Hungarian version of Vincent).

Description: Plants in herbarium pale brown, forming scattered colonies of 3-12 $\mathrm{mm}$ diameter on living dicotyledonous leaves. Shoots $0.8-0.95 \mathrm{~mm}$ wide. Stems up to $5 \mathrm{~mm}$ length, 30-60 $\mu \mathrm{m}$ thick, with 1 ventral merophyte. Cross section terete with 5-6 rows of cortical and 1 row of medullary cells. Rhizoids forming about $150 \mu \mathrm{m}$ wide rosettes near each leaf base, colourless, 10-12 $\mu \mathrm{m}$ wide, at their end often bifurcate. Leaves broad ovate, somewhat asymmetric, falcate, 5-600 $\times 280-400 \mu \mathrm{m}$, ventral lobe margin forms an angle of $70-90^{\circ}$ to the stem. Lobe apex acuminate or sometimes obtuse, margin entire and often with one interrupted row of hyaline border with rectangular or irregular shaped dead cells. Basal lobe cells 24-38 × 10-20, median 20-30 × 16-22, apical 10-20 × 7-12 $\mu \mathrm{m}$, with moderately incrassate walls, small trigones and on part of them with 1-2 intermediate thickenings. About on $25 \%$ of the cells bear round papillae on their dorsal wall. The hyaline border cells with very thin walls without thickenings. Lobule inflate, ovate, $30-40 \%$ of lobe length, $50-80 \times 25-50 \mu \mathrm{m}$, at its base with a larger socle cell. Median cells isodiametric or slightly rectangular with moderately thickened walls, very small trigones, without intermediate thickenings and papillae. First tooth 1-2 celled with a hyaline papilla on its ental side. Second tooth obsolete or completely missing. The keel joins the postical lobe margin with a very wide angle or continuous.

Autoicous. Antheridia on short side branches or at shoot apex, up to 600 $\mu \mathrm{m}$ length and $300 \mu \mathrm{m}$ width. They consist of $4-8$ pairs of male bracts, each up to $200 \mu \mathrm{m}$, ovate-lanceolate with acuminate apex sometimes tipped by 1-2 hyaline cells. Their lobule about half length of the lobe. Archegonia on the side or apex of shoot or branches, with one innovation. Female bracts cuneiform, 
usually with hyaline apex, reaching $3 / 4$ length of the mature perianth, with lobule about $30 \%$ of lobe length. Perianth obpyriform, $600 \times 400-450 \mu \mathrm{m}$, with moderately compressed side wings and a strongly inflated ventral segment.
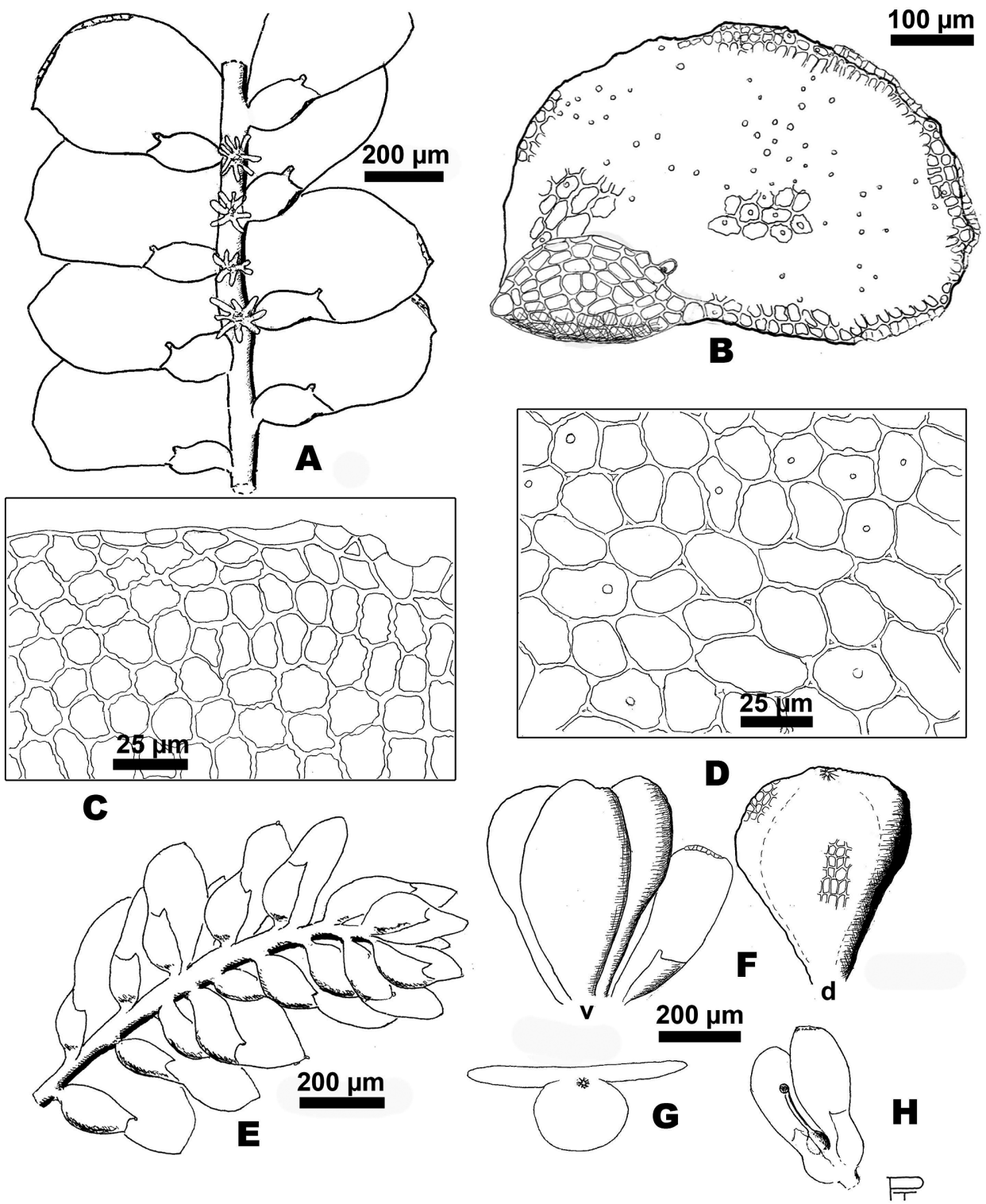

Fig. 1. Cololejeunea bencei Pócs, spec. nova (all from the type, 01161/H): $\mathrm{A}=$ habit, ventral view; $\mathrm{B}=$ leaf, ventral view; $\mathrm{C}=$ leaf margin with hyaline border cells; $\mathrm{D}=$ basal and median leaf cells; $\mathrm{E}=$ male branch; $\mathrm{F}=2$ different perianths, ventral $(\mathrm{v})$ and dorsal $(\mathrm{d})$ view; $\mathrm{H}=$ archegonium with two young female bracts 
Perianth wall formed by $20-25 \mu \mathrm{m}$ isodiametric cells with moderately thickened walls. Perianth apex umbilicate with a pore without beak, surrounded star-like with border cells of incrassate wall, in the near horizontal plane of perianth apex, similarly to the atming pores of Marchantiales. Sporophyte and vegetative ways of reproduction are unknown.

The new species seems to be endemic to the Venezuelan Guayana. By the acuminate leaf lobe tipped by hyaline cells the new species is similar to the neotropical Cololejeunea ecuadoriensis Pócs and C. minutilobula Herzog, but C. ecuadoriensis Pócs lacks styli and C. minutilobula Herzog has a very different lobule.

\section{ENUMERATION OF THE OTHER COLLECTED SPECIES}

Almost all species cited below were epiphyllous and collected at the same locality as the new species; two were corticolous (see text). Nomenclature follows Söderström et al. (2016). Synonyms are cited for recently changed names. General distribution is given in detail, with references for less common species. Records new to Venezuela (marked by asterisk) are based on Dauphin et al. (2008) and Morales et al. (2007).

Bazzania hookeri (Lindenb.) Trevis. - No 01161/A - Accidentally epiphyllous, very widespread neotropical species.

Ceratolejeunea cornuta (Lindenb.) Steph. - No 01161/B - Widespread, probably pantropical species.

Cheilolejeunea lineata (Lehm. et Lindenb.) Schiffn. (Syn.: Cystolejeunea lineata (Lehm. et Lindenb.) A. Evans) - No 01161/D - A Caribbean-SE Brazilian species (Gradstein 2021).

Cheilolejeunea cf. lobulata (Lindenb.) Gradst. et C. J. Bastos. (Syn.: C. oncophylla (Ångstr.) Grolle et Reiner) - No 011061/E - Differs from the typical forms by relatively small trigones of leaf cells. Widely distributed in the Neotropics (Grolle and Reiner-Drehwald 1997).

Cheilolejeunea rigidula (Nees et Mont.) R. M. Schust. (Syn.: C. serpentina (Mitt.) Mizut.) - No 01161/F - Widespread pantropical species (Gradstein 2021).

Cheilolejeunea trifaria (Reinw., Blume et Nees) Mizut. - No 01161/H Widespread pantropical species.

Cololejeunea camillii (Lehm.) A. Evans - No 01161/J - Widespread neotropical species (Pócs et al. 2014).

${ }^{*}$ Cololejeunea cardiocarpa (Mont.) A. Evans - No 01161/N (Fig. 2C-D). Widespread pantropical species, yet not yet recorded from Venezuela. Further Venezuelan records: Estado Mérida, Parque Nacional Sierra de la Culata N. de Mérida, coll.: S. \& T. Pócs con estudiantes, (9726/BR); Parque Nacional Sierra Nevada, la Mucuy E de Tabay, coll.: S. \& T. Pócs (05023/AC); Carratera Mérida-La Culata, debajo El Valle, coll.: S. \& T. Pócs (05038/BB). 
Cololejeunea microscopica (Tayl.) Smith - No 01161/K - Widespread pantropical and oceanic temperate species (Pócs et al. 2014, Gradstein 2021).
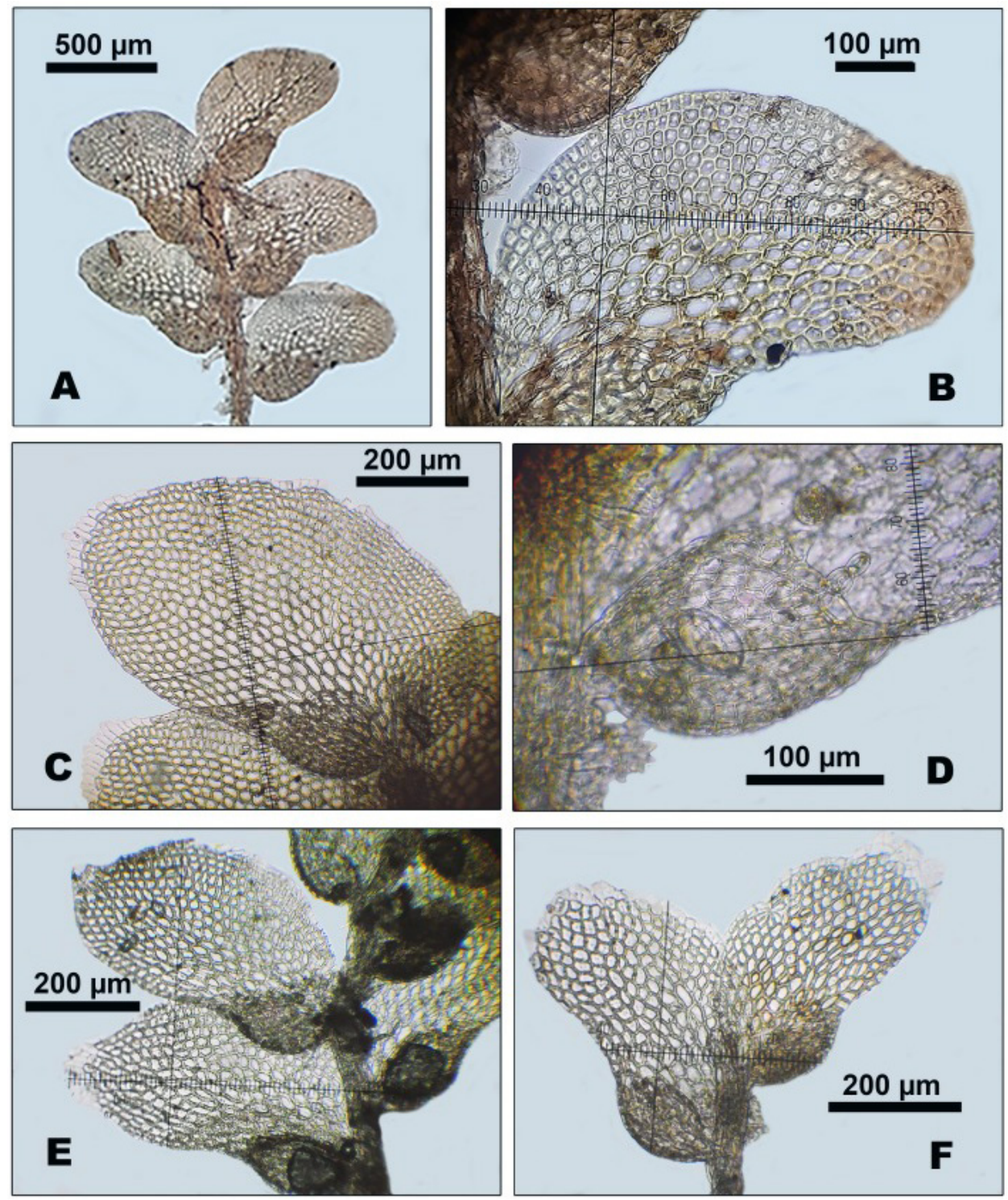

Fig. 2. A-B = Cololejeunea platyneura (Spruce) A. Evans, habit and leaf, ventral view (from B. Pócs, 01161/L); C-D = Cololejeunea cardiocarpa (Mont.) A. Evans, leaf and lobule, ventral view (from B. Pócs, 01161/N); E = Cololejeunea schusteri Pócs, habit, ventral view (from B. Pócs 01161/M); F = Cololejeunea aff. schusteri Pócs, habit, ventral view (from Galápagos Islands, Schäfer-Verwimp 9301) 
${ }^{*}$ Cololejeunea obliqua (Nees et Mont.) Schiffn. - No 01161/Q - A widespread pantropical species (Pócs et al. 2014), not known before from Venezuela. Further Venezuelan record: Edo Bolivar, Rio Caura, Salto Pará, coll.: D. Balázs (Ven. 9/H), 8 October 1977).

${ }^{*}$ Cololejeunea platyneura (Spruce) A. Evans - No 01161/L (Fig. 2A-B). - A relatively rare pantropical species. In tropical America hitherto only known from Panama, Brazil, French Guiana and Ecuador (Dauphin 2007, Gradstein 2021, Schäfer-Verwimp et al. 2013) and Peru (new record, Prov. Coronel Portillo, Distr. Iparia, coll.: J. G. Graham \& J. Schuke Vigo, (4630/H)), new to Venezuela.

${ }^{*}$ Cololejeunea schusteri Pócs - No 01161/M (Fig. 2E). - Hitherto known only from Brazilian Amazonia (Pócs 2002). Further new records: Venezuela, Parque Nacional Henri Pittier N of Maracay, coll.: S. \& T. Pócs (05056/AA); Panama, Barro Colorado Island, coll.: G. Dauphin (3153). The species is related to $C$. cardiocarpa, but the two can be separated easily by their different lobe and lobule shape (Pócs 2002). A specimen from Ecuador, Galápagos Islands, Santa Cruz, coll.: Schäfer-Verwimp \& Verwimp (9301) (Fig. 2F), identified by R. Grolle as C. cardiocarpa, has the lobe shape like C. schusteri while the lobule is more like in C. cardiocarpa. Its taxonomic position should be clarified based on further Galápagan specimens.

Cololejeunea subsphaeroidea (R. M. Schust.) Pócs - No 01161/O - This species was originally described from the Sierra Nevada de Mérida (Venezuela) (under the name Aphanolejeunea subsphaeroidea, Schuster 1978) and has since been found also in Brazil, Dominican Republic, Ecuador and in French Guiana (Schäfer-Verwimp and Pócs 2009), in Guadeloupe (Schäfer-Verwimp et al. 2013) and in Panama (Schäfer-Verwimp 2014). The species is very tiny and easily overlooked; probably it is more widespread in the Neotropics.

${ }^{*}$ Cololejeunea verwimpii Tixier - No 01161/N and P (Fig. 3A). - Widespread but scattered in the Neotropics (Schäfer-Verwimp et al. 2013); new to Venezuela. Further Venezuelan records: Cordillera del Norte, Laguna del Viso NW of Mérida, coll.: T. Pócs \& M. S. Ussher (0220/AC); P. N. Sierra Nevada, La Mucui E de Tabay, coll.: S. \& T. Pócs (05023/AD); Edo. Mérida, caratera Mérida-La Culata, debajo El Valle, coll.: S. \& T. Pócs (05038/BA).

Colura greig-smithii Jov.-Ast - No 01161/R - Rare and scattered in the Neotropics. In Venezuela the species was only known from Alto Orinoco, Surumoni (Dauphin et al. 2008).

Cyclolejeunea convexistipa (Lehm. et Lindenb.) A. Evans - No 01161/S - A very widespread neotropical species.

Diplasiolejeunea brunnea Steph. - No 01161/T - A very widespread neotropical species. 
Diplasiolejeunea cavifolia Steph. - No 01161/U - A widespread pantropical species.

Diplasiolejeunea pellucida (Meissn.) Schiffn. - No 01161/V - A widespread neotropical species.

Drepanolejeunea bidens (Steph.) A. Evans - No 01161/W - A common neotropical species, distributed from Florida and Mexico to Colombia, Ecuador and Brazil (Bischler 1964, Gradstein 2021).
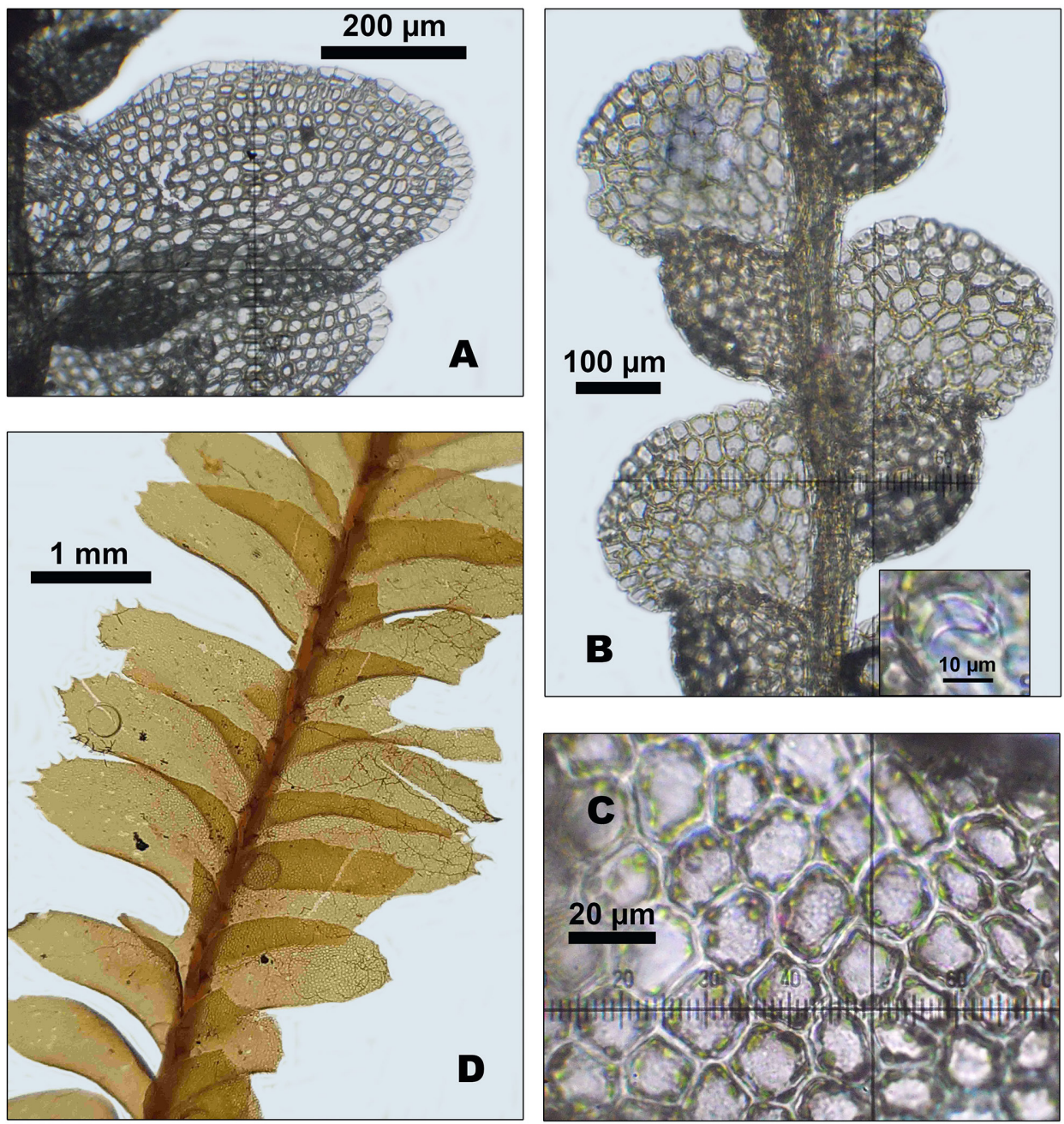

Fig. 3. A = Cololejeunea verwimpii Tixier, leaf, ventral view (from B. Pócs, 01161/P); B-C = Lejeunea pulchra C. J. Bastos et Gradst., B = habit, ventral view, $\mathrm{C}=$ lobe cells (from B. Pócs, 01161/AB); D = Plagiochila crispabilis Lindenb., habit, dorsal view (from B. Pócs 01161/AG) 
Drepanolejeunea biocellata A. Evans - No 01161/X - A widely distributed neotropical species from Mexico to Bolivia and Brazil.

Drepanolejeunea crucianella (Tayl.) A. Evans - No 01161/Y - This tiny liverwort, especially its small form earlier called $D$. trifida Steph., covered large portions of the collected leaves. It is common from the Caribbean islands to Brazil.

Drepanolejeunea inchoata (Meissn.) Steph. - No 01161/Z - A very common neotropical species (Gradstein 2021).

Drepanolejeunea mosenii (Steph.) Bischler - No 01161/AA - Widespread from subtropical America to Brazil (Gradstein 2021).

*Lejeunea pulchra C. J. Bastos et Gradst. - No 01161/AB (Fig. 3B-C) - This tiny species is hitherto known only from the type described from the state of Bahia, Brazil (Bastos and Gradstein 2020). It is well characteristised by the leaves directed forward, imitating a Microlejeunea, its papillose cuticle, strongly inflated lobuli with small, curved tooth and relatively wide underleaf lobes.

Lejeunea flava (Sw.) Nees - No 01161/AB - A very common pantropical species.

Lepidozia cupressina (Sw.) Lindenb. - No 01161/AD, collected from tree bark. - A bipolar temperate species widespread also in tropical American and African mountains (Pócs et al. 2016).

Leptolejeunea elliptica (Lehm. et Lindenb.) Steph. - No 01161/AE - A common neotropical species.

Odontolejeunea lunulata (Weber) Schiffner - No 01161/AF - A very widespread epiphyllous tropical Afro-American disjunct species, which was described from Africa under the name of O. tortuosa (Lehm. et Lindenb.) Steph. (Gradstein 2013).

*Plagiochila crispabilis Lindenb. (Syn.: P. patentissima Lindenb.) - No 01161/ AG (Fig. 3D), collected from tree bark. - A species common in eastern Brazil, not yet known elsewhere (Gradstein and Costa 2003, Gradstein 2021). Its occurrence in the Venezuelan Guayana is a meaningful extension of its known distribution area. Its distinguishing characters are the terminal branching and the rectangular leaves with parallel, almost straight margins without border (Gradstein 2016, 2021).

Rectolejeunea versifolia (Schiffn.) L. Söderstr. et A. Hagborg. (Syn.: R. berteroana (Steph.) A. Evans) - No 01161/AH - A widespread neotropical species (Reiner-Drehwald and Grolle 2012, Söderström et al. 2015, Gradstein 2021).

\section{DISCUSSION}

The relatively high number of epiphyllous species on the rather few living leaves collected (ca. 0) is indicative of favourable microclimatic habitat conditions. The species composition of the collected epiphylls is presumably 
characteristic of the tepui foothills in the Venezuelan Guayana, in view of the common presence of Amazonian and Brazilian species, like Cheilolejeunea lineata, Cololejeunea schusteri, Lejeunea pulchra and Plagiochila crispabilis. The high number of species new to the country ( $1 / 4$ of all collected species) shows the still inadequate knowledge of the bryoflora of the Venezuelan Guayana, in spite of numerous collections made at higher altitudes on the tepuis by Steyermark (Fulford 1967, Morales et al. 2007).

A group of species related to the worldwide distributed Cololejeunea cardiocarpa seems to have evolved in the Neotropics, many more than in other continents. These include C. ecuadoriensis, C. microandroecia, C. minutilobula, C. schusteri, C. subcardiocarpa and C. verwimpii. A molecular taxonomic study should be carried out on this interesting species complex. The taxonomic position of the $C$. schusteri-like population of $C$. cardiocarpa on the Galápagos Islands also needs further work.

Acknowledgements - I am grateful to my son Bence Pócs, cartographer and tour operator, for collecting epiphyllous bryophytes. Many thanks are due also to the reviewers, Prof. Stephen Robbert Gradstein and Dr Alfons Schäfer-Verwimp for the useful corrections and additions.

\section{REFERENCES}

Bastos, C. J. P. and Gradstein, S. R. (2020): The genus Cheilolejeunea (Marchantiophyta: Lejeuneaceae) in tropical America. - Nova Hedwigia 111(3-4): 287-335. https://doi.org/10.1127/nova_hedwigia/2020/0596

Bischler, H. (1964): Le genre Drepanolejeunea Stephani en Amérique Centrale et Méridionale. - Rev. Bryol. Lichénol. 33: 15-179.

Dauphin, G. (2007): Nuevas adiciones de especies de hepáticas para la flora de Panamá. Candollea 62: 45-51.

Dauphin, G., Morales, T. and Moreno, E. J. (2008): Catálogo preliminar de Lejeuneaceae (Hepaticae) de Venezuela. - Cryptogamie, Bryol. 29(3): 41-77.

Fulford, M. (1967): Hepaticae. In: Steyermark, J. A. (ed.): Flora del Auyan-tepui. - Acta Bot. Venezuelica 2(5-8): 5-370.

Gradstein, S. R. (2013): Afro-American hepatics revisited. - Polish Bot. J. 58(1): 149-177. https://doi.org/10.2478/pbj-2013-0016

Gradstein, S. R. (2016): The genus Plagiochila (Marchantiophyta) in Colombia. - Rev. Acad. Colomb. Cienc. Ex. Fis. Nat. 40(154): 104-136. https://doi.org/10.18257/raccefyn.272

Gradstein, S. R. (2021): The liverworts and hornworts of Colombia and Ecuador. - Mem. New York Bot. Gard. 121: 1-719.

Gradstein, S. R. and Costa, D. P. (2003): The Hepaticae and Anthocerotae of Brazil. - Mem. New York Bot. Gard. 87: 1-318. 
Grolle, R. and Reiner-Drehwald, M. E. (1997): Cheilolejeunea oncophylla (Angstr.) Grolle \& Reiner comb. nov. (Lejeuneaceae), from the Neotropics. - J. Bryol. 19(4): 781-785. https://doi.org/10.1179/jbr.1997.19.4.781

Mizutani, M. (1961): A revision of Japanese Lejeuneaceae. - J. Hattori Bot. Lab. 24: 115-302.

Morales, T., García, M. and Avendaño, N. (2007): Especies venezolanas de hepáticas (Marchantiophyta) pertenecientes al Herbario Nacional de Venezuela (VEN). - Cryptogamie, Bryol. 28(1): 41-77.

Pócs, T. (2002): New or little known epiphyllous liverworts, IX. Two new Neotropical Cololejeunea species. - Acta Bot. Hung. 44(3-4): 371-382. https://doi.org/10.1556/abot.44.2002.3-4.13

Pócs, T., Bernecker, A. and Tixier, P. (2014): Synopsis and key to species of Neotropical Cololejeunea (Lejeuneaceae). - Acta Bot. Hung. 56(1-2): 185-226. https://doi.org/10.1556/abot.56.2014.1-2.14

Pócs, T., Ochyra, R. and Bednarek-Ochyra, H. (2016): Lepidozia cupressina (Marchantiopsida, Lepidoziaceae) in sub-Saharan Africa, with a note on the taxonomic status of L. chordulifera. - Cryptogamie, Bryol. 37(2): 125-147. https://doi.org/10.7872/cryb/v37.iss2.2016.125

Reiner-Drehwald, M. E. and Grolle, R. (2012): Review of the genus Rectolejeunea (Lejeuneaceae, Marchantiophyta). - Nova Hedwigia 95: 451-482. https://doi.org/10.1127/0029-5035/2012/0063

Schäfer-Verwimp, A. (2014): Towards a more complete knowledge of the liverwort flora of Panama. - Phytotaxa 173: 201-234. https://doi.org/10.11646/phytotaxa.172.3.3

Schäfer-Verwimp, A. and Pócs, T. (2009): Contribution to the hepatic flora of the Dominican Republic, West Indies. - Acta Bot. Hung. 51(3-4): 367-425. https://doi.org/10.1556/ABot.51.2009.3-4.13

Schäfer-Verwimp, A., Lehnert, M. and Nebel, M. (2013): Contribution to the knowledge of the bryophyte flora of Ecuador. - Phytotaxa 128(1): 1-63. https://doi.org/10.11646/phytotaxa.128.1

Söderström, L., Stotler, R. E., Gradstein, S. R., Barrie, F. R., Hagborg, A., Crandall-Stotler, B. J. and von Konrat, M. (2015): Notes on early land plants today. 73. Genera of Lejeuneaceae established in the period 1884-1893: dates of validation and implications. Phytotaxa 220(2): 143-198. https://dx.doi.org/10.11646/phytotaxa.220.2.4

Söderström, L., Hagborg, A., von Konrat, M., Bartholomew-Began, S., Bell, D., Briscoe, L., Brown, E., Cargill, D. C., Costa, D. P., Crandall-Stotler, B. J., Cooper, E. D., Dauphin, G., Engel, J. J., Feldberg, K., Glenny, D., Gradstein, S. R., He, X., Heinrichs, J., Hentschel, J., Ilkiu-Borges, A. L., Katagiri, T., Konstantinova, N. A., Larraín, J., Long, D. G., Nebel, M., Pócs, T., Puche, F., Reiner-Drehwald, E., Renner, M. A. M., Sass-Gyarmati, A., Schäfer-Verwimp, A., Segarra-Moragues, J. G., Stotler, R. E., Sukkharak, P., Thiers, B. M., Uribe, J., Váňa, J., Villarreal, J. C., Wigginton, M., Zhang, L. and Zhu, R.-L. (2016): World checklist of hornworts and liverworts. - PhytoKeys 59: 1-828. https://doi.org/10.3897/phytokeys.59.6261

Open Access statement. This is an open-access article distributed under the terms of the Creative Commons Attribution 4.0 International License (https://creativecommons.org/ licenses/by/4.0/), which permits unrestricted use, distribution, and reproduction in any medium, provided the original author and source are credited, a link to the CC License is provided, and changes - if any - are indicated. (SID_1) 